\title{
総合健診での大腸癌のスクリーニング に打ける精検の進め方
}

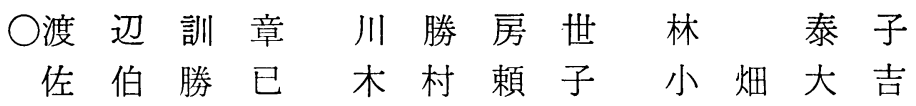

私共の施設では, 大腸癌のスクリーニングを便潜血反 応之自覚症状等で行なっている。昭和 58 年度からは, 便潜血反応にへモカルトIIスライド 3 回法を 4 日間の食 事制限により実施した。このへモカルトIIスライドは, てれまでに使用してきたへマテスト，潜血スライド，へ モカルトスライドの中で, 大腸癌の発見率はへマテスト と共に $0.12 \%$ と高率を示した。そして，とのへモカル トIIスライドを用いた 3 年度間の癌 発見率は, 58 年度 $0.07 \%, 59$ 年度 $0.13 \%, 60$ 年度 $0.14 \%$ と上昇し, 又精 検受診率は各 $79.9 \% ， 85.1 \% ， 84.6 \%$ となった。

さて, 大腸癌発見率向上には精密検査 (以下精検之略 す）の精度を良くすること, 便潜血反応の再検査（以下 再検と略す) 及び精検の指示された者が, 全員受診する 事が重要である。所が大腸癌の精検は胃の精検に較べ, 未だ一般の人には㓮染みが薄い等敬遠される傾向にあ る。又, 食事制限の失敗等による便潜血反応再検におい ては，再度の食事制限が煩わしいので放置されることが 多い。

我々の場合, 昭和 58 年から昭和 60 年の 3 年度間の精 検受彮率は平均 $83 \%$ とまずまずであったが，再検率は $62.7 \%$ 之極めて低率であった。これらの率の改善が癌発 見率の向上に大切である。そこで, 便潜血反応陽性者を 中心として便潜血反応の再検及び精検の追跡を行なっ た。即ち 3 年度間の計 1.022 例の便潜血反応陽性者か ら，264 例（25.8\%）はいきなり精検の指示を受け, 内 の 225 例（85.2\%）が精検受診した結果 96 例 (42.7\%) に各種疾患（癌, ポリープ, 䕀室）を認め大腸癌 9 例が 発見された。
いきなり精検の指示をせず，便潜血反応再検を指示さ れた者が残りの 758 例 (74.2\%) あり，内の 475 例 (62.7 \%)のみが再検を受けた結果，103例が陽性を呈し，77 例 (74.8\%) が精検を受けて，30 例 (37.7\%) に各種疾 患を認め大腸癌 3 例が発見された。しかし，いきなり精 検の指示をされ乍ら末精検のまま放置された 39 例(14.8 \%) 及び，再検を指示され乍ら未再検のまま放置してい る 283 例 (37.3\%) 又, 再検を受診し陽性を呈した者で 未精検のままが 26 例 (25.2\%) あった。それら未再検, 未精検の計 348 例の中にふるい落ちた大腸癌が含まれて いると考えられる。

以下てれら 348 例の中に含まれている大腸癌を推定し てみる。今, 未再検者及び末精検者が全員もれなく精検 を受診したと仮定すると，いきなり精検の指示をされ精 検を受診した 225 例から 9 例の大腸癌が発見された時と 同様の率で大腸癌が発見されたとすると，39例 の未精 検者から 1 人強の大腸癌が発見される。

同様に再検を指示され末再検であった者 283 例から 1.8 人新たに発見されることになり, 又再検にて陽性で 未精検者 26 例から 1.6 人発見出来るととになる。こう して結局 4.3 人発見癌が増える計算になる。乙れは全発 見大腸癌 12 例の $33 \%$ に当たる。但してれは最大限の見 積むりと考えられる。

さて今後の再検, 精検からの脱落防止対策としては, 再検又は精検を勧める時にその意義をよく説明すると共 に, ロビーに便潜血反応の意義について解説したポスタ 一を貼る。或は大腸癌について解説したパンフレットを ロビーに置く等であった。

\footnotetext{
Procedure for the Close Examination of ColoRectal Cancer in our MHTS

大手前病院 健康管理センター
} 